\title{
Knowledge Management, Entrepreneurial Skills and Innovation towards Informal Entrepreneurs (Food Services) Success in Malaysia
}

\author{
Nazatul Shima Abdul Rani \\ Universiti Kuala Lumpur \\ UniKL Business School \\ Kuala Lumpur \\ Malaysia \\ K. Sarojani Devi Krishnan \\ Universiti Kuala Lumpur \\ UniKL Business School \\ Kuala Lumpur \\ Malaysia \\ Zainon Che Mat \\ Faculty of Entrepreneurship and Business \\ Universiti Malaysia Kelantan \\ Kampus Pengkalan Chepa \\ Kota Bahru, Kelantan
}

\begin{abstract}
The purpose of this research is to investigate the relationships between knowledge management, entrepreneurial skills, and innovation toward informal entrepreneur success. About 180 questionnaires were distributed randomly to micro and small food business owner within Klang Valley, and 150 questionnaires returned (83.33\% response rate).The finding shows that innovation, knowledge management, and entrepreneurial skills have direct influence towards informal entrepreneur success in Klang Valley, Malaysia. The limitations of the finding only can be generalized to micro and small food business owner within Klang Valley, Malaysia. The findings are useful for future micro and small food entrepreneur or informal entrepreneur to be successful in their business. More training on knowledge management, entrepreneurial skills, and innovation should be in place to ensure micro and small food business success in the future. The most interesting finding from this research shows that the most important factor for informal food entrepreneur success is innovation followed by knowledge management, and finally, entrepreneur skills.
\end{abstract}

Keywords: informal entrepreneurs, knowledge management, entrepreneurial skill, innovation, food business owner, Klang Valley, Malaysia.

\section{Introduction}

In creating high income country status, Malaysia has made a drastic change for economic development and Government had set up the New Economic Model (NEM) for Malaysian from a middle income to radical nation by 2020 (Malaysia Economic Report, 2012). Bhowmik (2005) mentioned that people who are not having high skill and good education migrated from the village to urban area looking for better job opportunities however their skills incompatible with the formal sector that resulted them to join informal sector for survival.

The improvement of food industry also parallel with the modernization, which is supported by entrepreneur's by not giving up in the entrepreneurial (Nor Aini and Siwar, 2003). The examples of informal business in the informal economy in Malaysia are known as hawkers. In Malaysia, majority of the informal traders can be found either in the day at 'PasarTani' or at night at 'PasarMalam'. In fact, the Ministry of Women (2014) has identified most women entrepreneur are involved in the informal business sector such as tailoring, cake sellers, on-line businesses, and others.

Yet, to date, studies on knowledge management, entrepreneurial skill, and innovation involving Malaysian informal business sector is still limited. This research is carried out with the aim to examine to the effects of the relationship between the knowledge management, entrepreneurial skills, and innovation on the informal business sector success, particularly within the context of informal entrepreneurs in Malaysia. 


\section{Literature Review}

There are few studies specifically to identify the effects of knowledge management, entrepreneurial skill and innovation towards informal entrepreneur's success in Malaysia. There are a few researches conducted within Malaysian context by previous scholars such as Yi and Jayasingam, (2012) has studied on the factors influencing knowledge creation among private sector organizations. Other studies on Malaysian informal entrepreneur includes examining the factors which motivate women's informal micro-entrepreneurs in Malaysia (Anja, 2012), and examined the organizational learning as a mediator in the relationship between knowledge management, and innovation (Kambiz \& Aslan, 2014).

\subsection{Knowledge Management}

Beijerse (2000) has described knowledge as the foundation of knowledge management and its primary to something that makes both data and information manageable. The knowledge management may include the entirely of systems of which the information within an organization can be managed and extracted easily. The key factor for entrepreneurs to be successful in global economy is due to knowledge management that considers people skills as the most important assets in business. The intangible resources the company can offer, the higher the possibility in creating competitive advantage for the business (Tanoira, \& Valencia, 2014). Egbu and Ranukappa (2005) highlighted that knowledge generated in SMEs is tacit in nature due to various reasons, and some elements of knowledge management in informal business are practiced in an 'ad hoc' manner.

\subsection{Entrepreneurship Skills}

Entrepreneurship skills can be defined as identification of customer needs, technical or market opportunities, and pursuing business opportunities (Hayton, 2015). McLarty and Dousios (2006) defined skill as competence, proficiency, attributes, and the ability to do something well in relation to knowledge, expertise, and capability. Exposure of entrepreneurs into new ideas and approaches is one of the factors associated with developing entrepreneurship skills, both at a local and international level (Rodriguez-Pose \& Hardy, 2015). In short, the leadership skills and entrepreneurship skills is a mixed between the development of strategy formalization and responsiveness. This is the factors that are positively associated with performance and growth.

\subsection{Innovation}

Innovation is defined as the ability to introduce a new process, product or idea in the company (Hurley \&Hult, 1998). According to Maravelakis and Moustakis (2006), they measured firm's innovation based on the product, process and administrative innovation.Innovation as a term is not only related to products and processes, but it is also related to marketing and management (Gunday, Ulusoy, Kilic, \&Alpkan, 2011). Schumpeter (1989) had described an innovation as bringing new products, introducing new methods of production, new sources of supply, the exploitation of new markets, and new ways to organize business in industry.

\subsection{Entrepreneur Success}

The success of entrepreneurs is measured by either financial or non-financial such as the ability to operate more than three years continuously in trading activities (Abdul Manaf\& Yee, 2012; Powell \&Eddleston, 2012). Steffens and Fitzsimmons, (2012), agreed that the entrepreneurial success is also variously measured by using the criteria such as growth, and profitability that is categorized as financial success, whereas survival goal, and lifestyle success can be categorized as non-financial success.

\subsection{The Relationship between Knowledge Management, Entrepreneurship Skills, and Innovation with Entrepreneur's Success}

This conceptual framework is developed based on knowledge management theory (Darroch, 2005), entrepreneurial skills (Morales, 2013), and innovation theory (Price, Stoica, \& Boncella, 2013). Figure 1 illustrates the framework that underpins this study, and preceding paragraphs forwarded hypotheses for this study.

\subsubsection{Knowledge Management and Informal Entrepreneur Success}

Knowledge management puts the best practices through transferring appropriate knowledge as well as aiding the decision makers in many ways in organizations by dealing with different resources (Hartono and Halim, 2014). Darroch (2005) stated that knowledge management has direct influence on innovation and firm performance. Yazhou and Jian (2013) found that the best practices through transferring appropriate knowledge can benefit organizations for sustainable competitiveness. Thus, the empirical studies by scholars have proven that there are positive relationships between the variables, as this hypothesis is forwarded: 
H1: There is a significant and positive relationship between knowledge management practices towards informal entrepreneur's success

\subsubsection{Entrepreneurial Skills and Informal Entrepreneur Success}

Entrepreneurial skills are about supporting entrepreneurs to success, the generation of new ideas and the exploitation of the company thinking power (Cooney, 2012). Entrepreneurial competencies are strong predictors of successful entrepreneurial activities (Ahmad \&Kummerow, 2010), hence it can be assumed that entrepreneurial skills are believed to have direct influence on informal business success. Thus, the second hypothesis is forwarded:

H2: There is a significant influence and positive relationship between entrepreneurial skills towards informal entrepreneur's success.

\subsubsection{Innovation and Informal Entrepreneur Success}

Hernández-Espallardo and Delgado-Ballester (2009) had found that innovation can improve the business performance. There is a relationship between innovation and firm performance that includes introduction of products, processes, and market innovations towards firm growth (Atalay \& Sarvanc, 2013; Murat Ar and Baki (2011). According to the above theories and substantial evidences, the third hypothesis is forwarded:

H3: There is a significant and positive relationship between innovations towards informal entrepreneur's success.

Independent Variables

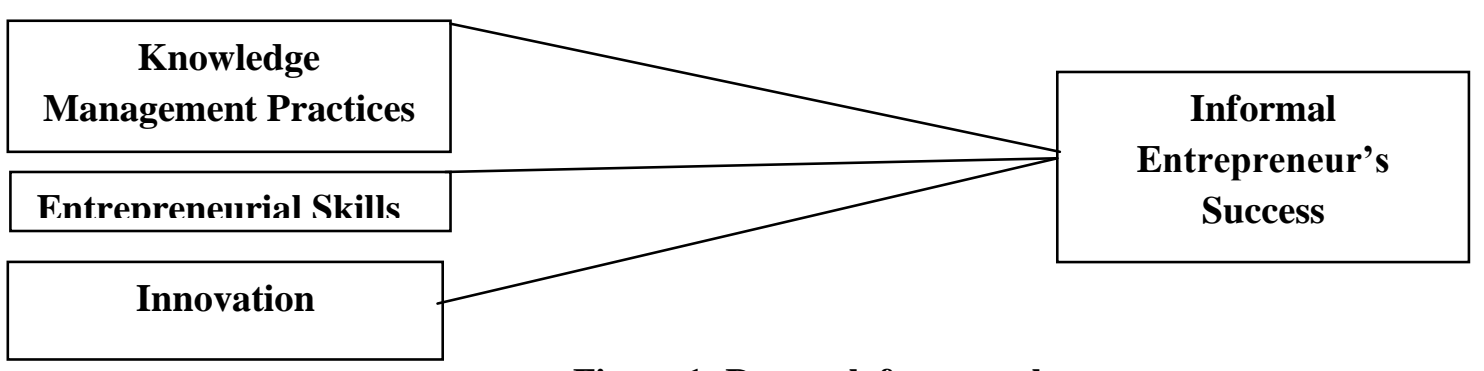

Figure 1: Research framework

\section{Methodology}

Creswell (2009) recommended three types of research design in analyzing data, namely qualitative, quantitative and mixed methods. The author also justified that quantitative method is for testing objective theories by examining the relationship among the variables. A structured questionnaire was developed to obtain the responses from informal entrepreneurs about their opinions on various research variables.

\subsection{Sample}

In the study, word sample of population refers to the entire group of people, ideas, variables or other phenomena possessing common traits (Sekaran \& Roger, 2013). Hillebrandt (2000), most economists used the word "firm" to refer to the business unit. Target samples are informal entrepreneurs at Kuala Lumpur urban area, age between 21 to 65 years old and their education backgrounds are varies. The sampling method that was adopted in this study for data collection was convenience sampling method through a questionnaire survey with 180 respondents for sample size.

\subsection{Questionnaire Design}

The questionnaire in this study consists of three sections, namely section A, B, and C. The last section consists of demographic questions whilst the rest consist of items relating to the constructs. These constructs were assessed on a seven-point Likert scale from 1 being 'strongly disagree' to 7 being 'strongly agree', where the Likert type scale is a common approach used to measure a wide variety of latent constructs (Kent, 2001). The survey questionnaire in this research consisted of validated measurement that was adapted from the previous literatures. Section A involves requesting the respondents to provide information on knowledge management practices. Section B aims to obtain some information on their entrepreneurial skills. Section C is about the implementation on business innovation and section D is to examine the respondents on business success. Last section E, request for demographic profile such as gender and their family entrepreneurship background. Table 1 shows the main construct, total of scale items used and sources of the items to measure each construct. 
Table 1: Factors

\begin{tabular}{llll}
\hline Factors & $\begin{array}{l}\text { Number } \\
\text { of Items }\end{array}$ & Sources \\
\hline Knowledge & 15 items & $\begin{array}{l}\text { Abdullah \&Egbu, 2010; Chen \& Mohamed, 2010; Donate \& Canales, } \\
\text { Management }\end{array}$ & $\begin{array}{l}\text { 2012; Gunday, et. al, 2011; MohdRosli\&Syamsuriana, 2013; } \\
\text { Muhammad Saqib\&Sadia, 2014. }\end{array}$ \\
\hline Entrepreneurial Skills & 9 items & Morales \&Marqu, 2013 \\
\hline Innovation & 15 items & $\begin{array}{l}\text { Atalay\&Sarvanc, 2013; Donate, 2012; Gunday, et. al., 2011; } \\
\text { Muhammad Najib\&Azlina, 2010; MohdRosli\&Syamsuriana, 2013. }\end{array}$ \\
\hline Entrepreneur Success & 10 items & Gunday, et al., 2011; Zhang and Xia, 2010 \\
\hline
\end{tabular}

\subsection{Data Collection}

According to Sekaran and Roger, (2013), 100 to 500 samples are large enough and appropriate upper limit for a sample size to generalize the population. Questionnaire distribution is an efficient data collection method because it provides opportunity for researcher to administer the distribution personally (Sekaran, 2003). Before testing the hypotheses in this study, the responses received were analyzed to determine the reliability of the questionnaires. Total of 180 questionnaires were distributed to all informal entrepreneurs within Klang Valley area and 150 surveys were returned equivalent to 83.33 percent response rate. Another of 30 questions was unreturned and the study continued the analysis with valid questionnaires total of 150 items using SPSS.

\section{Analysis}

This section presents the results of this study. Data collected from the survey was analyzed by the statistical software SPSS version 19.0.

\subsection{Demographic Profile}

As shown on Table 2, $47.3 \%$ of the respondents are male and the remaining of the respondents are female $(52.7 \%)$. The highest group of respondents with the aged of 41 until 50 years old is about $29.3 \%, 22 \%$ at the age of 21 to 30 years old, and $8 \%$ of the respondents at the age of 51 to 60 years old. The lowest number of respondents come from the aged range 61 years and above which comprises only 1.3\%. Race, shows that Malay respondents comprise of 54.7\%, Indian with $25.3 \%$ and Chinese was about $20.0 \%$ of the total respondents.

About $61.3 \%$ of the respondents are married, $24.7 \%$ are single, and $14 \%$ are divorcee. $70 \%$ of the respondent education level is at secondary level, $24.7 \%$ at either college or university level, and $5.3 \%$ at the primary level. The informal business has been in operation from 5 to 10 years about $45.3 \%, 30.1 \%$ for the last 10 to 15 years, less than 5 years at $15.30 \%$ and more than 15 years is about $9.3 \%$. About $69.3 \%$ have worked in private sector, $14 \%$ in government sector, and $16.7 \%$ has never worked before.

Table 2: Demographic Characteristics

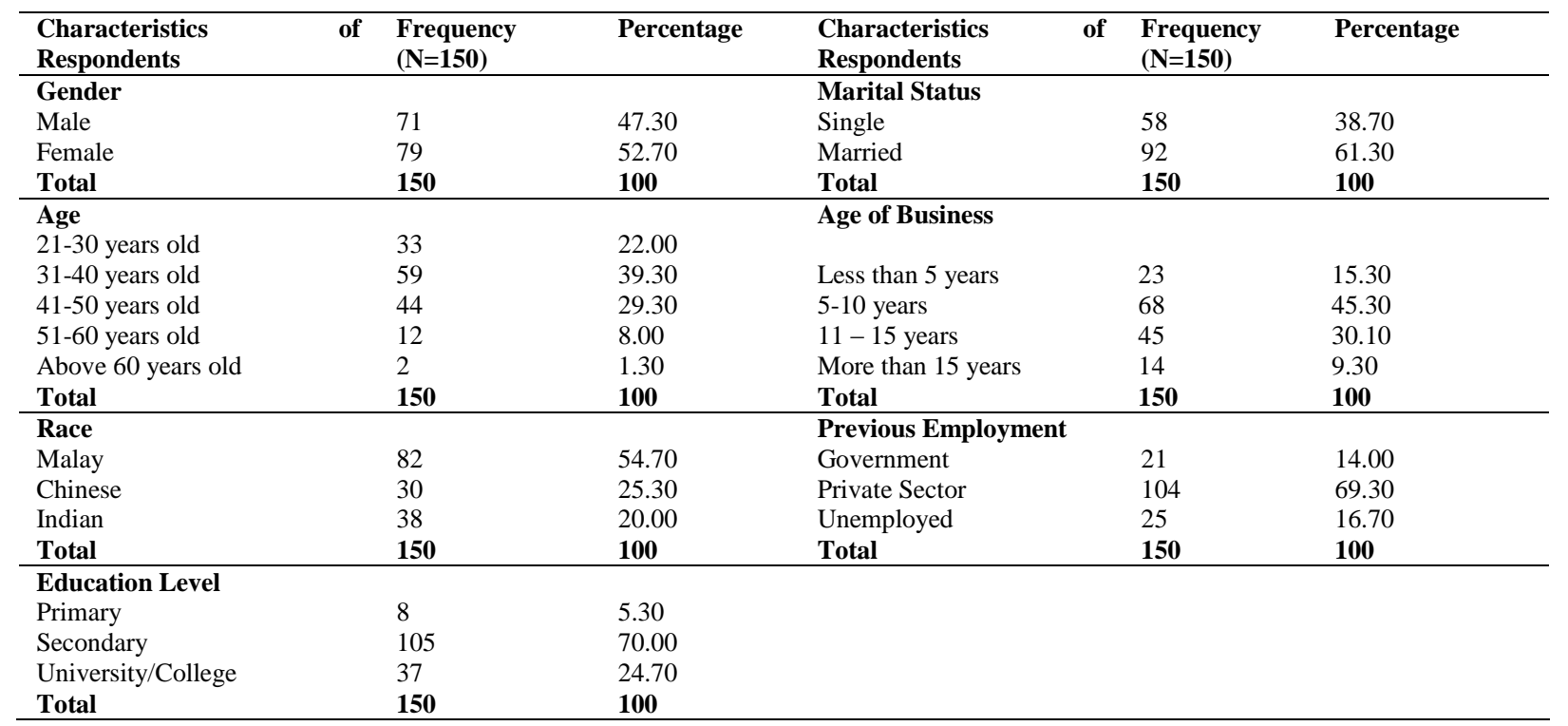




\subsection{Normality Test}

Table 3 below has shown the Skewness and Kurtosis values, all the variables value is within the range (-2 to 2), hence the distribution of the data for the sample is considered normal (Chua, 2008). The Skewness values were negative for all variables, its means that the distribution is flatter than normal. The Kurtosis of a normal distribution is zero and the study shows almost of the variable's Kurtosis values are negative. Therefore, the negative value shows that the distribution is flatter than a normal distribution. According to Hair and Sarstedt (2014), has stated that the value of Skewness and Kurtosis are within of +-1.96 is indicates rejecting of the normality assumptions level of probability at 0.05. Therefore, the study cannot reject the normality of distribution because the data is considered as normally distributed.

Table 3: Test of Normality

\begin{tabular}{lllll}
\hline Measurement & Mean & Std. Deviation & Skewness & Kurtosis \\
\hline Responsive to knowledge & 29.11 & 2.78 & -0.34 & 0.36 \\
Knowledge acquisition & 29.26 & 2.46 & -0.30 & 0.01 \\
Knowledge dissemination & 29.29 & 2.43 & -0.17 & 0.03 \\
Entrepreneur skill & 53.53 & 4.35 & -0.89 & 0.39 \\
Product innovation & 28.77 & 2.61 & -0.26 & 0.52 \\
Process innovation & 28.99 & 2.21 & -0.54 & 1.35 \\
Marketing innovation & 29.17 & 2.19 & 0.00 & -0.23 \\
Entrepreneur Success - Financial & 23.67 & 1.86 & 0.27 & 0.72 \\
Entrepreneur Success - Non-Financial & 35.12 & 2.60 & -0.24 & 0.61 \\
\hline
\end{tabular}

\subsection{Reliability}

As shown on Table 4, all of the Cronbach's alpha coefficients for the items scale were greater than 0.6 , hence no items deleted. The Cronbach's Alpha test was used as a reliability coefficient that indicates how well the terms in a set are positively correlated to one another. The results of this test show that all variables in this study are reliable being KM practices (0.883), Entrepreneurial Skill (0.838), Innovation (0.856) and Informal entrepreneur's success (0.856).

Table 4: Reliability analysis

\begin{tabular}{llll}
\hline Factors & Cronbach's Alpha & $\begin{array}{l}\text { Number } \\
\text { Deleted }\end{array}$ & $\begin{array}{l}\text { Item } \\
\text { Kotal Number } \\
\text { of Items }\end{array}$ \\
\hline Knowledge Management & 0.893 & 0 & 15 \\
Entrepreneurial Skills & 0.850 & 0 & 9 \\
Innovation & 0.866 & 0 & 15 \\
Entrepreneur Success & 0.764 & 0 & 10 \\
\hline
\end{tabular}

\subsection{Correlation Analysis of Entrepreneurial Factors and Entrepreneurial Success}

Correlation measures the strength and the direction of relationship using Pearson correlation to measure the significance of linear bivariate between the independent and dependent variables thereby achieving the objective of this study as proposed by Sekaran (2003). The findings tabulated in table 5, shows the value of correlation coefficient, " $r$ " is positive. Thus, the relationships between the variables are positive relationship with the $r$ ranging value between 0.281 and 0.544, It is apparent that all entrepreneurial factors have a significant relationship with informal entrepreneurial success $(\mathrm{p}<0.01)$.

\subsubsection{Knowledge Management}

The Pearson Correlation Analysis shows that there is positive and significant relationship between, knowledge management with innovation ( $\mathrm{r}=0.723)$, entrepreneurial skills $(0.588)$ and informal entrepreneur success $(0.525)$. Thus, it can be concluded that the higher the knowledge management being practiced by the informal entrepreneur the higher the innovation, and the entrepreneurial skills of the informal entrepreneur. In addition, knowledge management also has positive and significant relationship toward informal entrepreneur success.

\subsubsection{Innovation}

The Pearson Correlation Analysis shows that innovation has positive and significant relationship with knowledge management $(r=0.723)$, informal entrepreneur success $(r=0.544)$ and also entrepreneurial skills $(r=0.530)$. Hence, it can be concluded that the higher the innovation in the business the higher the knowledge management, informal entrepreneur success, and also, entrepreneurial skills of an informal entrepreneur. 


\subsubsection{Entrepreneurial Skills}

The Pearson Correlation Analysis shows that entrepreneurial skills have positive and direct relationship with knowledge management $(\mathrm{r}=0.588)$, innovation $(\mathrm{r}=0.530)$, and informal entrepreneur success $(\mathrm{r}=0.281)$. In short, it can be concluded that the higher the entrepreneurial skills of an informal entrepreneur the higher the knowledge management, innovation, and also entrepreneur success.

Table 5: Correlation Analysis

\begin{tabular}{|c|c|c|c|c|c|}
\hline Dimension & Item & $\begin{array}{l}\text { Knowledge } \\
\text { Management }\end{array}$ & Innovation & $\begin{array}{l}\text { Entrepreneurial } \\
\text { Skills }\end{array}$ & $\begin{array}{l}\text { Informal } \\
\text { Entrepreneur } \\
\text { Success }\end{array}$ \\
\hline $\begin{array}{l}\text { Knowledge } \\
\text { Management }\end{array}$ & $\begin{array}{l}\text { Pearson } \\
\text { Correlation } \\
\text { Significant(2- } \\
\text { tail) } \\
\mathrm{N}\end{array}$ & $\begin{array}{l}1 \\
150\end{array}$ & $\begin{array}{l}.723^{* *} \\
.000 \\
150\end{array}$ & $\begin{array}{l}.588^{* *} \\
.000 \\
150\end{array}$ & $\begin{array}{l}.525^{* *} \\
.000 \\
150\end{array}$ \\
\hline Innovation & $\begin{array}{l}\text { Pearson } \\
\text { Correlation } \\
\text { Significant (2- } \\
\text { tail) } \\
\mathrm{N} \\
\end{array}$ & $\begin{array}{l}.723^{* *} \\
.000 \\
150\end{array}$ & $\begin{array}{l}1 \\
150\end{array}$ & $\begin{array}{l}.530^{* *} \\
.000 \\
150\end{array}$ & $\begin{array}{l}.544^{* *} \\
.000 \\
150\end{array}$ \\
\hline Entrepreneurial Skills & $\begin{array}{l}\text { Pearson } \\
\text { Correlation } \\
\text { Significant (2- } \\
\text { tail) } \\
\mathrm{N}\end{array}$ & $\begin{array}{l}.588^{* *} \\
.000 \\
150\end{array}$ & $\begin{array}{l}.530 * * \\
.000 \\
150\end{array}$ & $\begin{array}{l}1 \\
150\end{array}$ & $\begin{array}{l}.281^{* *} \\
.000 \\
150\end{array}$ \\
\hline $\begin{array}{l}\text { Informal Entrepreneur } \\
\text { Success }\end{array}$ & $\begin{array}{l}\text { Pearson } \\
\text { Correlation } \\
\text { Significant (2- } \\
\text { tail) } \\
\mathrm{N}\end{array}$ & $\begin{array}{l}.525^{* *} \\
.000 \\
150\end{array}$ & $\begin{array}{l}.544 * * \\
.000 \\
150\end{array}$ & $\begin{array}{l}.281^{* *} \\
.000 \\
150\end{array}$ & $\begin{array}{l}1 \\
150\end{array}$ \\
\hline
\end{tabular}

**Correlation is significant at the 0.01 level (2 tailed)

*Correlation is significant at the 0.05 level ( 2 tailed)

\section{Discussion}

\subsection{Knowledge Management and Informal Entrepreneur Success}

The result shows that knowledge management is an important factor towards informal entrepreneur's success through sharing and utilizing of best practices, lesson learned, experiences, as well as creating new knowledge. The results are consistent with the previous studies (Hartono \&Halim, 2014).

\subsection{Innovation and Informal Entrepreneur Success}

The finding reveals that the implementation of innovation is perceived to be the best factor influencing informal entrepreneur success as compared to others factors. This is conceptually supported the previous studies. The innovation includes in promotion, e-marketing and enlarging potential demand towards business success (Lau \& Tang, 2010; Gunday et al., 2011).

\subsection{Entrepreneurial Skills and Informal Entrepreneur Success}

This study proved that entrepreneur skills effect the success of informal entrepreneurs. The chances of entrepreneurial success growing in the presence of personal characteristics and skills such as self-efficacy, ability to recognize opportunities, personal perseverance, human and social capital are increased (Hayton, 2015).

\subsection{Recommendation for Future Study}

For future study, a more detailed questionnaire with more specific questions could be more helpful to gain a better description of the stages of success of informal entrepreneurs.

\subsection{Conclusion}

Overall, the findings in this study provide useful insights on the effects of knowledge management, entrepreneurial skills, and innovation towards informal entrepreneur success in Klang Valley, Malaysia. Although, in earlier studies it shows that knowledge management is the key factors for entrepreneur success, however, in this study it shows that 
innovation has more influence towards informal entrepreneur success in Klang Valley, Malaysia. Thus, in order for informal sector to be sustainable the informal entrepreneur has to be more innovative in promotion, e-marketing and enlarging potential demand towards business success.

\subsection{References}

Abdul Manaf, A. O., \& Yee, L. K. (2012). Critical success factors of entrepreneurs in business. Journal of Social Sciences and Humanities, 34-45.

Abdullah, M., \& Egbu, C. (2010). Selection Criteria Framework For Choosing Industrialized Building Systems. In 26th Annual ARCOM Conference, Leeds, UK, Association of Researchers in Construction Management, 11311139.

Ahmad, N. R., \& Kummerow, L. (2010). Entrepreneurial Competency and Business Success Relationship Contingent Upon Business Environment? A Studi of Malaysian SMEs. International Journal of Entrepreneurial Behaviour \& Research, 182-203.

Anja, K. F. (2012). Factors motivating women's informal micro-entrepreneurship:Experiences from Penang, Malaysia. International Journal of Gender and Entrepreneurship, 65-78.

Atalay, M. A., \& Sarvanc, F. (2013). The Relationship Between Innovation and Firm Performance: An Empirical Evidence from Turkish Automotive Supplier Industry. Procedia-Social and Behavioral Sciences, 226-235.

Beijerse, R. P. (2000). Knowledge management in small and medium-sized companies: knowledge management for entrepreneurs. Journal of Knowledge Management, 162-179.

Bhowmik, S. (2005). Street vendors in Asia: a review. Economic and Political Weekly, 2256-64.

Chen, L., \& Mohamed, S. (2010). The strategic importance of tacit knowledge management activities in construction.Construction Innovation: Information, Process, Management, 138-163. http://doi.org/10.1108/147141 71011037165.

Chua, L. C. (2008). An exploration of job satisfaction and commitment of teacher educators. Jurnal Penyelidikan, 6583.

Cooney., T. M. (2012). Entrepreneurship Skills for Growth-Orientated Businesses. Skills Development for SMEs and Entrepreneurship.

Creswell, J. W. (2009). Research Design: Qualitative, Quantitative, and Mixed Methods Approaches. Los Angeles, CA: Sage.

Darroch, J. (2005). Knowledge management, innovation and firm performance. Journal of Knowledge Management, 101-115.

Price, D. P., Stoica, M., \&Boncella, R. J. (2013). The relationship between innovation, knowledge, and performance in family and non-family firms: an analysis of SMEs. Journal of innovation and Entrepreneurship, 2(1), 14.

Donate, M., \& Canales, J. (2012). A new approach to the concept of knowledge strategy. Journal of Knowledge Management, 22-44.

Egbu, C. O., \& Renukappa, S. H. (2005). Knowledge management for sustainable competitiveness in small and medium surveying practices. Structural Survey, 7-21.

Tanoira, F. G. B., \& Valencia, R. A. S. (2014). Knowledge Management, Entrepreneurial Competencies and Organizational Development in Micro and Small Enterprises in Rural Regions in The State of Yucatan, Mexico. European Scientific Journal, European Scientific Journal, 10(1), 177-193.

Günday, G. U., \& Alpkan, L. (2011). Effects of innovation types on firm performance. International Journal of Production Economics, 662-676.

Gunday, G., Ulusoy, G., Kilic, K., \&Alpkan, L. (2011).Effects of innovation types on firm performance. International Journal of production economics, 133(2), 662-676.

Hair Jr., J. F., \& Sarstedt, M. (2014). Partial Least Squares Structural Equation Modeling (PLS-SEM). . Thousand Oaks, California: SAGE Publications, Inc. Retrieved from http://hbanaszak.mjr.uw.edu.pl/TempTxt/HairEtAl_2013_A P.

Hartono, H., \& Halim, E. (2014). The Impact of Knowledge Management and Entrepreneur's Knowledge on Innovation and Firm Performance. Journal The WINNERS, Vol. 15 No. 2, 108-114.

Hayton, J. (2015). Leadership and management skill and entrepreneurial skills in SMEs. Warwick business school.

Hernandez-Espallardo, M., \& Delgado.B, E. (2009). Product innovation in small manufacturers, market orientation and the industry's fi ve competitive forces: Empirical evidence from Spain. European Journal of Innovation Management, 470-491.

Hillebrandt, P. (2000). Economic Theory and the Construction Industry. Basingstoke, UK: Macmillan. 
Hurley, R., \& Hult, G. (1998). Innovation, Market Orientation, and Organizational Learning: An Integration and Empirical Examination. Journal of Marketing, 42-54.

Kambiz, \& Aslan. (2015). The Impact of Knowledge Management on Organizational Innovation: An Empirical Study. Asian Social Science, http://dx.doi.org/10.5539/ass.v11n23p153 .

Kent, R. (2001). Data Construction and Data Analysis for Survey Research. Houndmills, Hants: Palgrave.

Lau. A, R. C., \& Tang, E. P. (2010). The impact of technological innovation capabilities on innovation performance: An empirical study in Hong Kong. Journal Science Technology Policy China, 163-186.

Maravelakis, E. B., \& Moustakis, V. (2006). Measuring and benchmarking the innovativeness of SMEs: A threedimensional fuzzy logic approach. Production Planning \& Control, 283-292.

McLarty, R., \& Dousios, D. (2006). Dynamics and patterns of skills within small and medium-sized enterprises. Strategic Change, 175-186.

Ministry of Women. (2014). Study To Support The Development Of National Policies And Programmes To Increase And Retain The Participation Of Women In The Malaysian Labour Force:Key Finding And Recommendation.

Mohd. Rosli, \& Syamsuriana, S. (2013). The Impact of Innovation on the Performance of Small and Medium Manufacturing Enterprises: Evidence from Malaysia. Journal of Innovation Management in Small \& Medium Enterprise, 1-16.

Morales, C., \& Marquina, P. S. (2013). Entrepreneurial Skills, Significant Differences between Serbian and German Entrepreneurs. Journal of CENTRUM Cathedra: The Business and Economics Research Journal, 6-1.

Muhammad Najib, R. Z., \& Azlina, M. Y. (2010). Internet business strategies by property companies in Asia. . 270289. http://doi.org/10.1108/0263747101106569.

Muhammad Saqib, N. M., \& Sadia, S. (2014). Impact of Knowledge Management Practices on Firm Performance: Testing the Mediation Role of Innovation in the Manufacturing Sector of Pakistan. Pakistan Journal of Commerce and Social Sciences, 8(1), 9.

Murat, I. M., \& Baki, B. (2011). Antecedents and performance impacts of product versus process innovation: Empirical evidence from SMEs located in Turkish science and technology parks. European Journal of Innovation Management, 172 - 206.

Nor Aini, H. I., \& Siwar, C. (2003). Kemiskinan Bandar dan Sektor Tidak Formal di Malaysia.

Powell, G., \& Eddleston, K. (2012). Linking family-to-business enrichment and support to entrepreneurial success: Do female and male entrepreneurs experience different outcomes? . Journal of Business venturing, 28,261280.

Rodriques-Pose, A., \& Hardy, D. (2015). Addressing poverty and inequality in the rural economy from a global perspective. Applied Geography.

Schumpeter, J. (1989). Essays on entrepreneurs, innovations, business cycles and capitalism (edited by Clemence RV). New Brunswick, NJ: Transaction Publishers.

Steffens, P. D., \& Fitzsimmons, J. (2012). Performance configurations over time: implications for growth-and profitoriented strategies; New Perspectives on Firm Growth. Cheltenham: Edward Elgar Publishing.

(2012). The Malaysia Economic Report. Putrajaya, Malaysia: Ministry of Finance, Malaysia.

Sekaran, U., (2003). Research method for business: A skill building approach. 4th edition: John Wiley \& Sons.

Sekaran, U., \& Roger, B. (2013). Research Methods for Business. Wiley (6th edition).

Yazhou, W., \& Jian, L. (2013). An empirical research on knowledge management orientation and organizational performance: the mediating role of organizational innovation. African Journal of Business Management, 7(8, 604-612. .

Yi, L. W., \& Jayasingam, S. (2012). Factors driving knowledge creation among private sector organization: Empirical evidence from Malaysia. ournal of Organizational Knowledge Management.

Zhang, X. S., \& Xia, B. (2010). Key competitiveness indicators for new real estate developers. . Journal of Financial Management of Property and Construction, 15(2) , 143-157. http://doi.org/10.1108/13664381011063430. 